\title{
Pre-Linnaean herbaria viva of Helwing in the collections of the National Library of Poland and the University of Warsaw
}

\author{
Krzysztof Spalik* \\ Department of Plants Systematics and Geography, Faculty of Biology, University of Warsaw, Aleje Ujazdowskie 4, 00-478 Warsaw, Poland
}

\begin{abstract}
Georg Andreas Helwing (1666-1748) was the author of two important early accounts on the flora of former East Prussia: "Flora qusimodogenita" and "Supplementum florae prussicae". Along with his son-in-law Matthias Ernst Boretius, he prepared several herbaria viva. Four of these herbaria survived until WWII; however, their whereabouts since WWII have been generally unknown. In this paper, two of these herbaria are described: one preserved in the collections of the National Library of Poland and another in the herbarium of the Faculty of Biology of the University of Warsaw. Both were formerly in the possession of the Königsberg city library. These herbaria document not only Helwing's studies on the native flora of Prussia but also his experiments with acclimation of exotic species in his garden in Stullichen (Stulichy, Poland). They are also an important source of vernacular Polish and German names of plants.
\end{abstract}

Keywords: botanic history; Boretius; ethnobotany; Helwing; herbarium vivum; Prussia

\section{Introduction}

Pre-Linnaean botanical collections are invaluable for the interpretation of early botanical accounts and species names and particularly for tracing the cultivation of exotic species. In this paper, I describe two extant pre-Linnaean herbaria preserved in the Polish National Library and the herbarium of the Faculty of Biology, University of Warsaw that are linked to the Prussian botanist Georg Andreas Helwing (1666-1748).

Although during his lifetime he was revered as "Prussian Pliny" or "Prussian Tournefort" [1], Georg Andreas Helwing has been almost completely forgotten. He was born in Angerburg (at present Węgorzewo, Poland) to a family of a Lutheran pastor. Continuing family tradition, he started theological studies at Alberts-Universität or Albertina in Königsberg (at present Kaliningrad, Russia). Refraining from obtaining a master degree at Albertina, he commenced a "Bildungsreise" continuing his studies in Wittenberg, Leipzig and Jena. In Jena, he also studied natural sciences, particularly botany, with Georg Wolfgang Wedel, a physician and botanist at the university. Having graduated from the university in 1688 , he carried on his botanical studies staying a year with Herman Boerhaave in

\footnotetext{
*Email: spalik@biol.uw.edu.pl
}

Handling Editor: Beata Zagórska-Marek
Leiden. Summoned by his father, he returned to Angerburg in 1691 to serve as his adjunct in the Lutheran parish and after the death of his father in 1705 he replaced him as the provost [1-3]. Although busy with his church duties, he did not renounce his botanical interests. He investigated the flora of the vicinity of Angerburg. He also acquired a patch of land in a neighboring village Stullichen (Stulichy, Poland), where he established an acclimation garden sowing seeds of exotic plants obtained from Johann Philipp Breyn, Christoph Ritter and Herman Boerhaave [4].

His major botanical work was "Flora qusimodogenita" [5], in which he enumerated indigenous plants of Prussia, not only identifying species listed in earlier accounts but also describing new ones. A continuation of this work was "Supplementum florae prussicae" [6]. Two important works of Helwing remained in manuscript: "Tournefortius Borussicus" and "Index plantarum latino-polonicus" [1]. The former may be identified with "Tournefortius prussicus, sive enumeratio plantarum in Prussia indigenarum, partim a scriptoribus Prussicis recensitarum, partim noviter detectarum, ad methodum Josephi Pittonis Tournefortii adornata” described by Georg Christoph Pisanski ([7], p. 549). Pisanski, a grandson of Helwing, wrote that the manuscript was known from several copies and the plants were arranged following the system of Tournefort allowing for identification based on diagnostic characters. The plant index with Latin and Polish names was kept in the City Library of Königsberg and was a major source for Rostafiński's [8] treatise on early vernacular Polish names of plants. 


\section{Extant herbarium materials associated with Helwing}

\section{Sherardian Herbarium (OXF)}

In the biographical note of Helwing for the Taxonomic Literature, Stafleu and Cowan [9] indicated that some of his herbarium material is kept at OXF. Indeed, several specimens that may be associated with Helwing are within the Sherardian Herbarium collection; the majority bear annotations by William Sherard (Serena Marner, Oxford, personal communication). A specimen of Quercus robur associated with Helwing but actually coming from Herman Boerhaave's suburban garden explains the provenance of this material. Helwing spent almost a year with Boerhaave in Leiden and having returned to Angerburg he kept in touch with the Dutch botanist and regularly exchanged plants and seeds with him. Boerhaave distributed this material to other botanists; based on his correspondence with Sherard, he also acted as an intermediary between the British botanist and his Prussian colleague [10].

\section{Herbaria viva}

Among the works of the Angerburg pastor, his biographers included several herbaria viva, some prepared with the assistance of his son-in-law Matthias Ernst Boretius $[1,7,11]$. According to Pisanski [7], the first herbarium initially consisted of two volumes in folio but with successive supplements it grew to six volumes. It was kept in the Castle Library of Königsberg. Other six-volume sets were sent to the Electorial Library in Dresden and to St. Petersburg. A copy was in the possession of Jacob Theodor Klein, a botanist from Danzig (Gdańsk, Poland). In the City Library of Königsberg there was a five-volume set described as "Matth. Ern. Boretii Herbarium vivum, plantarum et florum in Porussia nascentium methodo Tournefortiana, in classes divisum; adscriptis nominibus Plantarum Latinis, Germanicis, Polonicis, cum Indice. Vol. V" [12]. However, Pisanski [7] claimed that Helwing in fact prepared this herbarium while Boretius merely wrote plant names. A third Königsberg copy belonged to Carl Gottfried Hagen; the plants were arranged according to the system of Tournefort and annotated with Latin, German and Polish names ([11], p. 495). This copy was examined by Caspary [13], who described it as a set of five volumes in folio bound in pigskin.

The Dresden copy was burnt during the riots of 1848 [13]; the whereabouts of the St. Petersburg copy are unknown; at least, it has not been preserved in the collections of the Komarov Botanical Institute (personal inquiry). Jacob Klein sold his copy to Friedrich, margrave of Brandenburg-Bayreuth; it was kept in the collections of the University of Erlangen until the end of the 19th century when Hugo Conwentz acquired it by exchange for the collection of the Westpreussiches Landesmuseum in Danzig. After the Second World War, surviving botanical collections from this museum were transferred to the Nicolaus Copernicus University in Torun but Helwing's herbarium was not among them [4]. The fact that one of Helwing's herbaria viva has been preserved in the collection of the National Library in Warsaw has been known to Polish historians of botany [14]. The information on the preservation of another copy in the herbarium of the University of Warsaw has not been hitherto published.

\section{Herbarium vivum in the Polish National Library}

The herbarium set kept in the National Library in Warsaw includes two volumes; a third volume figuring in the catalogue has been obviously mistakenly associated with Helwing as it includes several loose herbarium sheets with plants named with Linnaean binomials. Both volumes are covered with lavishly decorated leather. Each volume also includes a watercolor illustrating the goddess Chloris (or Flora). In the first picture, she is assisting a botanist arranging plants in a herbarium book; a faun holding a cornucopia with flowers stands beside her (Fig. 1). The caption praises herbarium books ("Donec erunt herba, donec florentia serta herbarum, vivat florida fama libro"). The watercolor in the second volume illustrates Chloris in the clouds pointing to a female gardener carrying a basket of flowers. The caption expresses the goddess's surprise that out of the many plants so few are cultivated ("Hesperidum ingentes quorsum miraberis hortos, cum tot opes unus hortulus iste ferat?”).

The first volume bears the title "Herbarium Vivum Plantarum sponte in Prussia nascentium, Herculeo labore comparatum M. Georgii Andreae Helwingii Pastoris Angerburgensium. et Reg. Societ. Scient. Brand. Membrii”. The information about the membership of the Royal Brandenburg

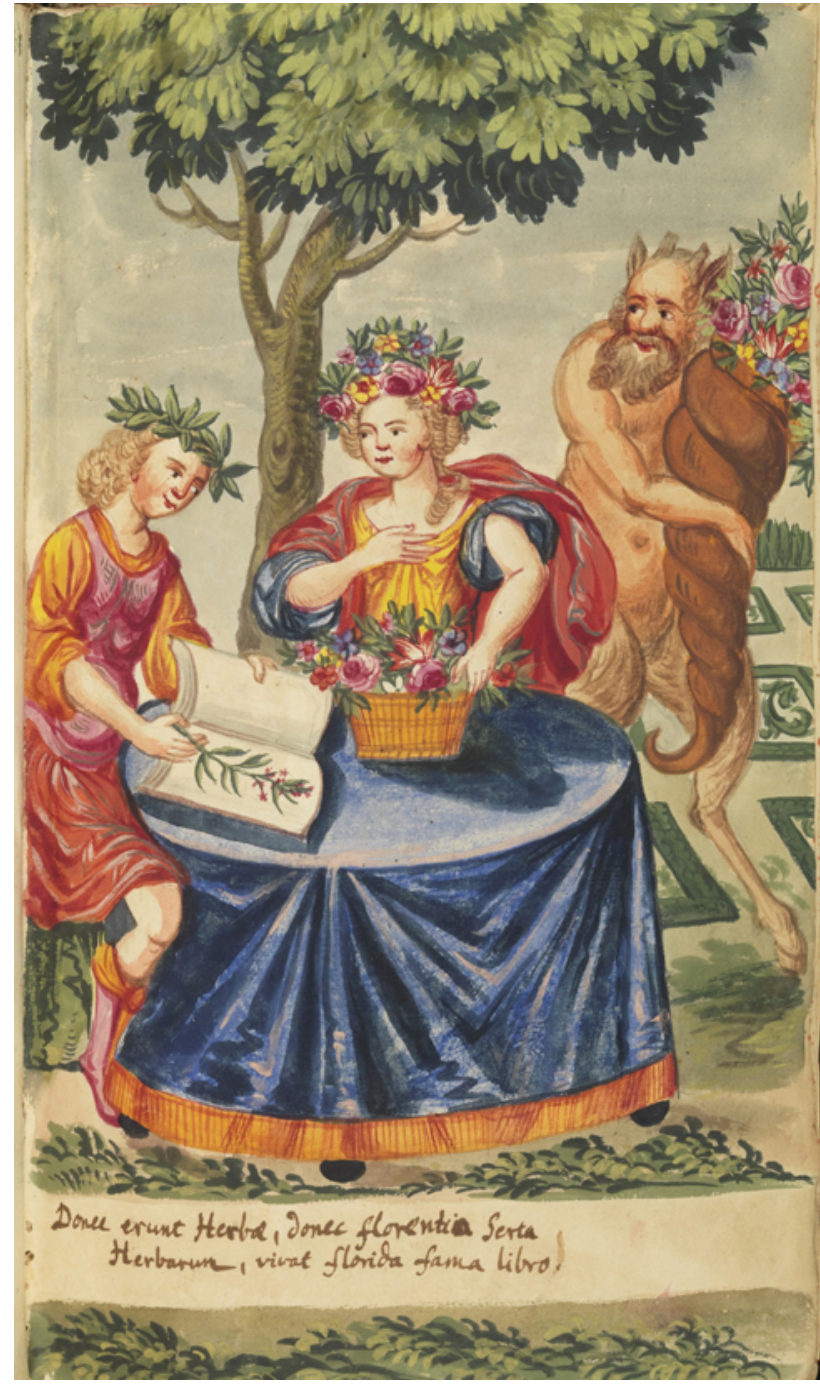

Fig. 1 The goddess Chloris assisting a botanist. Illustration from the first volume of Georg Andreas Helwing's herbarium vivum from the National Library of Poland. 
Scientific Society is written in different ink. Helwing was elected to the membership of the Berliner Akademie der Wissenschaften in 1709 [11]; the herbarium, therefore, must have been prepared before that date. The volume includes 449 pages with dried plants numbered 1-452; numbers 41, 155 and 403 are missing. The arrangement of plants does not follow any system; however, some natural groups (legumes, umbellifers, grasses etc.) are recognized. Each plant is annotated with a Latin phrasename without an authorship. Some specimens are also annotated with German and Polish names. As suggested by the title, this volume includes indigenous and naturalized species.

The title page of the second volume bears the sentence "Florae Napaeisque Sacrum! Civis, amice, advena, qui herbarii amoenitate cupis oblectarier, modestiam et continentiam comites habeas florae custodes, quod rogat, monet, expetit M. Georgius Andreas Helwing, pastor Angeburgensis, operis huius faber." It is a paraphrase of an inscription from public botanic and ornamental gardens summoning visitors to behave properly and to refrain from damaging the plants. Such warnings are known from the summerhouse of the botanic garden of the university of Altdorf ([15], p. 469) and from the ornamental garden of count Leonardo Valmarana in Vicenza ([16], p. 79-80). The sentence in Helwing's herbarium is almost an exact repetition of that in Altdorf and this connection may have had a special meaning. The botanical garden of Altdorf was the place where the ideas of the modern botanical garden and of investigating local flora were born, mostly due to the work of Ludwig Jungermann and Caspar Hoffman [17]. Opened in 1626, the garden constituted a "hortus publicus" and also served for the acclimation of exotic plants. In 1635, Jungermann published the catalogue of plants that survived German winters. In this catalogue, Jungermann placed both exotic and indigenous species. As Cooper [17] points out, for the German botanist, exotic plants in gardens and their local counterparts in surrounding fields were clearly at opposite poles of a rhetorical opposition, but they were at the same time linked by this very opposition. Similar parallelism of the local and the exotic may be seen in the work of Helwing. He investigated the flora of the vicinity of Angerburg while at the same time experimented with cultivation of exotic plants in his garden in Stullichen. The second volume of his herbarium vivum is a testimony to these efforts as it includes cultivated plants. The page following the watercolor with Chloris expressing her dissatisfaction with gardeners' efforts starts with an exclamation: "Chloris prussica fave!" meaning "Smile, Prussian Chloris", because numerous exotic plants are now being grown in "blessed land under the Prussian sky".

The pages with plants are numbered 1-195. Numbering is not continuous: numbers $126-159$ are missing and there is one page without a number inserted after page 37 . The majority of specimens in the second volume are botanical species; however, some ornamental varieties, for instance with double flowers, are also represented. Horticultural varieties include the members of Primula (p. 19-20, 181), Dianthus (p. 55), Delphinium (p. 110-111, 227), Aquilegia (p. 168-172) and Tulipa (p. 173-176, 222).

Both volumes bear a stamp of the City Library of Königsberg. However, this herbarium does not match the set that was kept in the City Library as described by Bernoulli and Pisanski but rather those two original volumes of the set from the Castle Library of Königsberg [7,12]. The herbarium is accessible on-line at the digital library Polona (http://www. polona.pl). The website is in Polish, a direct link to the first volume is http://polona.pl/item/7971108/0/ while the second volume is available at http://polona.pl/item/7971109/0/.

\section{Herbarium vivum at the University of Warsaw (WA)}

The set preserved in the herbarium of the Faculty of Biology originally comprised five volumes but only four have been preserved: volume 3 is missing. The volumes bear a stamp of the City Library of Königsberg. The covers are paperboard lined with parchment. The bindings of all volumes are damaged by fire; many pages are also partly burnt. Each volume has a title page with the number of the volume and the ordinal numbers of classes in the classification system of Tournefort. There is no title page to the entire herbarium and its author is not indicated. Pages with mounted plants are numbered and volume 5 includes Latin, German and Polish indices with reference to the volume, class and page number. Plants are not numbered continuously: in each class, the last number is omitted. Moreover, in volume 5 there are no plants on pages 31-67. Volume 1 comprises classes 1-4 (272 pages), vol. 2: 5-6 (274 pp.), vol. 4: 13-16 (272 pp.), vol. 5: 17-22 (175 pp.).

The herbarium includes mostly native species; there are no exotics as in the previously described set. However, some presumed garden escapes are present including tobacco (Nicotiana tabacum L.), cucumber (Cucumis sativus L.), ornamental hollyhocks (Alcea rosea L.), bladder cherry (Physalis alkekengi L.), lavender (Lavandula angustifolia Mill.) and others. Moreover, several varieties of native species are included, particularly those differing in color of flowers or with double flowers ("flore pleno"). They may comprise either rarely occurring natural forms of the species or their cultivated ornamental varieties. The plants are annotated with Latin phrasenames and, sometimes, German and Polish names. Some phrasenames are referred to Caspar Bauhin, Johann Bauhin, Johannes Loesel, Carolus Clusius, John Ray, John Parkinson, Joseph Pitton de Tournefort, Jacobus Theodorus Tabernaemontanus and others.

This set matches two Königsberg herbaria viva: the one that was initially kept in the City Library and the one that was in the possession of Hagen. Both comprised five volumes and were arranged according to the system of Tournefort, probably referring to the aforementioned Helwing's manuscript "Tournefortius prussicus". The set belonging to Hagen was examined by Caspary [13]. In his paper on Senecio vernalis Waldst. \& Kit., he described a specimen mounted on page 66 of volume 4 and annotated by Helwing or Boretius as "Jacobaea Senecionis folio incano perennis Raji hist. 285". The specimen was characterized as measuring $27 \mathrm{~cm}$ and having a rosette of ten leaves and two flower stalks with a single flowerhead preserved. The volume, the page number and the phrasename correspond to the herbarium vivum preserved in the collection of the University of Warsaw. However, the specimen does not match Caspary's description as it constitutes a flowering stem $25.5 \mathrm{~cm}$ long without a basal rosette, with five leaves and three head stalks; only two capitula are 
preserved. It seems, therefore, that this herbarium is not the copy belonging initially to Hagen but rather that attributed to Boretius and kept in the Stadtbibliotek Königsberg [7,11].

Helwing's herbarium vivum at WA has been digitalized. It has not been made accessible on-line yet but photos are available at request to the curator of the herbarium. Latin, German and Polish indices are accessible from the web page http://www.zielnik.biol.uw.edu.pl/?page_id=2941.

Apart from those four finished volumes, there are three additional volumes containing loose plants without any arrangement but labeled and apparently prepared for successive mounting. The first volume is bound in parchment with "Plantar[um] Exotic[um] tom. I." written on the spine. The two remaining volumes have cardboard covers. These volumes contain mostly exotic plants.

\section{The significance of Helwing's herbaria viva for taxonomy, botanical history and ethnobotany}

Similarly to many other pre-Linnaean publications, the works of Georg Andreas Helwing are mostly of historical interest. Although his two major floristic treatises, "Flora quasimodogenita" and "Supplementum florae prussicae", were known to Linnaeus and cited in the "Hortus Cliffortianus"

\section{Acknowledgments}

I am particularly grateful to Friederike Neuffer for her contribution in identifying the herbarium vivum at WA, I also thank Janina Andrearczyk, Maja Graniszewska, Łukasz Kozak, Charlie Jarvis, Serena Marner, Jarosław Sak, Maks Szot and Ewa Bartnik for their help during the research; this study was supported with the statutory funds of the Faculty of Biology, University of Warsaw.

\section{References}

1. Dunkel JGW. Historisch-critische Nachrichten von verstorbenen Gelehrten und deren Schrifften. Köthen: Cörner; 1757.

2. Sukertowa-Biedrawina E. Helwing - "Pliniusz pruski z Węgorzewa". Przegląd Zach. 1950;6:364-369.

3. Augusiewicz S, Jasiński J, Oracki T. Wybitni Polacy w Królewcu. Olsztyn: Wydawnictwo Littera; 2005.

4. Schwarz Z. Prywatne ogrody botaniczne a rozwój nauk przyrodniczych w ośrodku gdańskim w XVI-XVII wiekach. Kwart Hist Nauki Tech. 1986;31:411-444.

5. Helwing GA, Breyn JP. Flora quasimodogenita, sive enumeratio aliquot plantarum indigenarum in Prussia. Gdańsk: Joannes Daniel Stollius; 1712.

6. Helwing GA. Supplementum florae prussicae. Gdańsk: Thomas Johannes Schreiber; 1726.

7. Pisanski GC. Entwurf einer preußischen Literärgeschichte. Königsberg: Hartung; 1886.

8. Rostafiński J. Prowincyonalne, polskie nazwy roślin XVIII w., z Prus Książęcych głównie z rękopisu Andrzeja Helwinga. Rozpr Akad Umiejętności Wydz Filol. 1905;25:209-238.

9. Stafleu FA, Cowan RS. Taxonomic literature: a selective guide to botanical publications and collections with dates, commentaries and types. Utrecht: Bohn, Scheltema and Holkema; 1979. (vol 2).
[18], they do not seem to be a source of types for Linnaean names (Charles E. Jarvis, personal communication). Recently, Helwing's works were mostly cited in the context of history of botany in the former East Prussia [2-4]. However, they also constitute invaluable source documenting the spread of certain cultivars and naturalization of alien species [19-21], the more that Helwing's accounts may be now verified against his herbarium materials. For instance, Wein [19] discussed the spread of Jerusalem artichoke (Helianthus tuberosus L.) in Europe and noticed that Helwing listed this species in his "Flora quasimodogenita" as indigenous because "it grows in many Angerburg gardens without cultivation". This observation is documented in Helwing's herbarium with specimens of this species of sunflower. For Polish ethnobotanists, particularly valuable are glossas with Polish vernacular names. They allow for an interpretation of early ethnobotanical accounts.

Those two herbaria also illustrate the change that occurred in perceiving diversity of plants at that time. In the herbarium kept at the National Library, plants are shown as the gifts of Nature that should be studied for their potential use. The herbarium preserved in the collections of the University of Warsaw underlines that plants might be classified based on their internal features marking therefore the beginning of modern taxonomy.

10. Lindeboom GA. Boerhaave’s correspondence. Leiden: E.J. Brill; 1962.

11. Hagen KG. Bruchstücke zur Lebensbeschreibung des Probst Helwing zu Angerburg. Beitr. Zur Kunde Preußen. 1818;1:435-506.

12. Bernoulli J. Reisen durch Brandenburg, Pommern, Preußen, Curland, Rußland und Pohlen. Leipzig: Caspar Fritsch; 1779.

13. Caspary R. Senecio vernalis W. et K. schon um 1717 in Ostpreussen gefunden. Schriften Phys-Ökon Ges Zu Königsb. 1886;27:104-108.

14. Drobnik J. Zielnik i zielnikoznawstwo. Warsaw: Polish Scientific Publishers PWN; 2007.

15. Skippon P. An account of a journey made thro' part of the LowCountries, Germany, Italy, and France. In: Churchill A, Churchill J, editors. Collection of voyages and travels, some now printed from original manuscripts, others now first published in English. London: John Walthoe; 1732. p. 359-736.

16. Schott F, Capugnano H. Itinerarii Italiae rerumque Romanarum libri tres. Antwerp: Officina Plantiniana; 1625.

17. Cooper A. Inventing the indigenous: local knowledge and natural history in early modern Europe. Cambridge: Cambridge University Press; 2007.

18. Heller JL. Linnaeus's Hortus Cliffortianus. Taxon. 1968;17(6):663-719. http://dx.doi.org/10.2307/1218012

19. Wein K. Die Einführungsgeschichte von Helianthus tuberosus L. Kulturpflanze. 1963;11(1):41-91. http://dx.doi.org/10.1007/BF02136112

20. Wein K. Die Geschichte der Entstehung und Verbreitung von Rubus idaeus var. leucocarpus. Kulturpflanze. 1962;10(1):195-211. http:// dx.doi.org/10.1007/BF02095442

21. Wein K. Die Geschichte des Rettichs und des Radieschens. Kulturpflanze. 1964;12(1):31-74. http://dx.doi.org/10.1007/BF02095781 